\title{
Penerapan Konseling Behavior Untuk Mengurangi Kecenderungan Perilaku Konsumtif Mahasiswa Psikologi 2018 UIN Malang
}

\author{
Rifqi Minchatul 'Ulya \\ UIN Maulana Malik Ibrahim, Malang, Indonesia \\ rifqiulya19@gmail.com \\ Ahmad Fahmi Idris El Hakim \\ UIN Maulana Malik Ibrahim, Malang, Indonesia \\ fahmielafa@gmail.com \\ Muhammad Jamaluddin \\ UIN Maulana Malik Ibrahim, Malang, Indonesia \\ jamaluddin@psi.uin-malang.ac.id
}

\begin{abstract}
Abstrak
Penelitian ini bertujuan untuk mengungkap Penerapan Konseling Behavior Untuk Mengurangi Kecenderungan Perilaku Konsumtif Mahasiswa Psikologi 2018 UIN Malang. Penelitian tentang Penerapan Konseling Behavior Untuk Mengurangi Kecenderungan Perilaku Konsumtif ini dilakukan dengan menggunakan rancangan pre-experimental design berupa one group pretestposttest design. Untuk mengukur tingkat perilaku konsumtif dilakukan dengan menggunakan skala perilaku konsumtif yang sebelumnya telah dilakukan uji validitas $(\mathrm{V} \geq 0,87)$ dan reliabillitas $(\mathrm{r}>0,80)$. Analisis data menggunakan Uji Wilcoxon, hasil penelitian didapatkan Zhitung $>$ Ztabel atau 2,670 > 1,645 ( $\mathrm{p}<0,05)$, artinya Ha diterima dan Ho ditolak. Sehingga, hasil penelitian menunjukkan bahwa dapat dikatakan bahwa penerapan konseling behavior dapat menurunkan tingkat kecenderungan perilaku konsumtif mahasiswa psikologi angkatan 2018 UIN Malang. Saran bagi peneliti selanjutnya yang mengambil variabel sama dapat mengisi kekosongan dari sudut lainya seperti berfokus indikator minat dan opini yang belum mengalami penurunan secara signifikan, atau variabel permasalahnya lainnya
\end{abstract}

Kata Kunci: Perilaku Konsumtif, Konseling Behavior, Mahasiswa 


\begin{abstract}
Implementation of Behavior Counseling to Reduce the Tendency of Consumptive Behavior in 2018 Psychology College Students UIN Malang. This study aims to reveal the application of behavioral counseling to reduce the tendency of consumptive behavior in psychology students at UIN Malang. This research on the application of behavioral counseling to reduce the tendency of consumptive behavior was carried out using a pre-experimental design in the form of a one group pretest-posttest design. To measure the level of consumptive behavior, it is done using a consumptive behavior scale which has previously been tested for validity ( $V 0.87)$ and reliability $(r>0.80)$. Analysis of the data using the Wilcoxon test, the results of the study obtained Zcount > Ztable or 2,670 > 1,645 ( $p<0.05)$, meaning that Ha was accepted and Ho was rejected. Thus, the results of the study indicate that it can be said that the application of behavioral counseling can reduce the level of consumptive behavior in psychology students from the 2018 UIN Malang class. Suggestions for further researchers who take the same variables can fill in the blanks from other angles such as focusing on indicators of interest and opinions that have not decreased significantly, or other problematic variables..
\end{abstract}

Keywords : Consumptive Behavior, Counseling Behavior, College Student 


\section{A. Pendahuluan}

Mahasiswa merupakan bagian dari remaja, apabila disesuaikan dengan umur remaja masyarakat Indonesia. Mahasiswa merupakan peserta didik yang telah terdaftar di sebuah lembaga pendidikan tinggi yang bernama Universitas dan telah memenuhi persyaratan sebagai mahasiswa yang telah ditetapkan oleh Universitas. Mahasiswa sama halnya dengan masyarakat pada umumnya yang mempunyai keinginan dalam pemenuhan akan kebutuhannya. Kebutuhan mahasiswa terdiri dari alat tulis kerja, buku paket kuliah, transportasi dari rumah ke kampus dan sebaliknya serta alat penunjang lainnya yang menjadi keperluan masa perkuliahan, untuk memenuhi kebutuhan tersebut tentunya terdapat pengeluaran yang dilakukan. Pemenuhan kebutuhan penting untuk mengantarkan individu pada kehidupan yang selaras dengan lingkungannya.

Pada umumnya setiap orang khususnya mahasiswa akan melakukan kegiatan konsumsi dan menyukai terhadap hal-hal yang berbau konsumtif seperti senang berbelanja. Membeli sesuatu untuk memenuhi kebutuhan sebenarnya tidak menjadi masalah bahkan sudah menjadi hal yang lumrah pada kehidupan seharihari, selama membeli itu benar-benar ditunjukkan untuk memenuhi kebutuhan hidup yang pokok atau benar-benar dibutuhkan atau disebut dengan kebutuhan primer. Seperti contoh membeli handphone untuk alat komunikasi. Namun, yang akan menjadi permasalahan apabila dalam usaha pemenuhan kebutuhan tersebut mahasiswa mengembangkan perilaku yang mengarah pada kecenderungan konsumtif.

Strategi yang dapat digunakan untuk menangani perilaku konsumtif berdasarkan asumsi behavioral dari Skinner adalah behavioral contract dan reinforcement. Behavioral Contract (Kontrak Perilaku) adalah persetujuan antara dua orang atau lebih (konselor dan klien) untuk mengubah perilaku tertentu pada klien, (Latipun, 2008). Kontrak berisi persetujuan tertulis dari pihak-pihak yang terlibat dalam proses konseling, utamanya konselor dan konseli tentang berbagai hal yang berhubungan dengan proses konseling seperti peran dan tanggung jawab, bentuk penguatan dan sanksi yang akan diberikan, aturan pemberian penguatan, 
dsb (Eko Darminto, 2007). Penggunaan teknik behavioral contract didasarkan pada pandangan bahwa penghentian perilaku menyimpang pada mahasiswa harus disertai dengan hadiah tertentu sesuai dengan perjanjian yang disepakati dan sebaliknya.

\section{B. Metode}

Penelitian dilaksanakan di Fakultas Psikologi UIN Maulana Malik Ibrahim Malang pada mahasiswa psikologi angkatan 2018. Sedangkan untuk waktu pelaksanaan penelitian pemberian layanan konseling behavior yaitu dilaksanakan pada tahun ajaran 2020/2021. Adapun metode dalam penelitian yang digunakan adalah metode Quasi Experiment. Seperti halnya menurut Suryabrata (2012) menyatakan bahwa penelitian eksperimental semu atau Quasi Experiment secara khas mengenai bentuk dan keadaanya tidak memungkinkan untuk mengontrol semua variabel yang relevan kecuali beberapa dari variabel tersebut. Desain dalam penelitian ini yang digunakan peneliti adalah One-Group Pre-test and Post-test Design, adapun yang artinya yaitu dengan memberikan Pre-test sebelum memberikan perlakuan dan memberikan Post-test setelah diberikan perlakuan kepada mahasiswa. Adapun dalam penelitian ini adalah upaya untuk mengurangi perilaku konsumtif pada mahasiswa psikologi UIN Malang angkatan 2018 melalui konseling behavior. Adapun subyek penelitian dalam penelitian ini adalah mahasiswa psikologi UIN Malang angkatan 2018 yang memiliki kecenderungan perilaku konsumtif tinggi pada setiap indikator. Untuk mendapatkan subjek penelitian, peneliti menggunakan teknik Purposive Sampling untuk pengambilan sampel. Dalam penjaringan subyek, peneliti melakukan penyebaran skala perilaku konsumtif. Dalam penelitian ini didapatkan 9 subyek penelitian yang kemudian diberikan perlakuan konseling behavior.

Uji validitas digunakan untuk mengetahui apakah instrumen yang dibuat dapat mengukur apa yang diinginkan. Untuk itu sebelum intrumen tersebut 
digunakan, terlebih dahulu perlu di uji cobakan. Tujuannya agar dapat diketahui apakah instrumen yang digunakan tersebut memiliki validitas yang tinggi atau rendah. Analisis data yang digunakan dalam penelitian ini adalah dengan uji Wilcoxon Matched Pairs Test yaitu dengan mencari perbedaan mean Pretest dan Posttest. Instrumen dalam penelitian ini menggunakan skala perilaku konsumtif mengikuti model Likert. Skala gaya hidup konsumtif digunakan untuk memperoleh data tentang penurunan perilaku konsumtif pada siswa yang dijabarkan dalam bentuk kisi-kisi yang telah disajikan. Mahasiswa diminta untuk memilih salah satu jawaban yang sesuai dengan keadaan diri dengan cara memberikan tanda ceklis $(\sqrt{ })$. Dimana dalam skala model Likert, mahasiswa akan diberikan pernyataanpernyataan dengan alternatif pilihan jawaban, yaitu: sangat setuju (SS), setuju (S), tidak setuju (TS), sangat tidak setuju (STS).

Hasil perhitungan skala perilaku konsumtif yaitu menunjukan bahwa skala yang digunakan memiliki reliabilitas sebesar 0,850. Berdasarkan kriteria reliabilitas maka reliabilitas tersebut termasuk dalam kriteria sangat tinggi. Adapun dengan demikian, dapat disimpulkan bahwa instrumen dalam penelitian ini dapat digunakan. Dikarenakan subjek penelitian kurang dari 25, maka distribusi datanya dianggap tidak normal (Sudjana, 2005) dan data yang diperoleh merupakan data ordinal, maka statistik yang digunakan adalah non parametrik (Sugiyono, 2010) dengan menggunakan Uji Wilcoxon Matched Pairs Test. Penelitian ini akan menguji Pretest dan Posttest. Dengan demikian peneliti dapat melihat perbedaan nilai antara Pretest dan Posttest melalui uji Wilcoxon ini. Dalam pelaksanaan uji Wilcoxon Matched Pairs Test untuk menganalisis kedua data yang berpasangan tersebut, maka dapat dilakukan dengan cara yaitu analisis uji melalui program SPSS. 


\section{Pembahasan}

\section{Perilaku konsumtif}

Menurut Anggasari dalam Hotpascaman (2010:2) Perilaku konsumtif adalah membeli barang yang kurang atau tidak diperhitungkan sehingga sifatnya menjadi berlebihan. Perilaku konsumtif tersebut juga menggambarkan kecenderungan pola hidup individu yang didorong oleh suatu keinginan untuk memenuhi hasrat kesenangan semata-mata (Subandy, 1997). Berdasarkan pendapat para ahli di atas dapat disimpulkan bahwa perilaku konsumtif merupakan tindakan penggunaan barang dan jasa yang lebih berfokus pada keinginan bukan kebutuhan dan cenderung berlebihan dengan tujuan menaikkan prestise.

Adapun indikator gaya hidup konsumtif menurut Sumartono (2002), memaparkan bahwa secara operasional indikator perilaku konsumtif diantaranya :

a. Membeli produk karena iming-iming hadiah. Hal ini memberikan pemikiran pada konsumen bahwa hanya dengan membayar satu produk, konsumen akan mendapatkan produk lebih.

b. Membeli produk karena kemasannya menarik. Artinya motivasi untuk membeli produk tersebut hanya karena produk tersebut dibungkus dengan rapi dan menarik.

c. Membeli produk demi menjaga penampilan diri dan gengsi. Mahasiswa membelanjakan uangnya lebih banyak untuk menunjang penampilan diri agar terlihat menarik.

d. Membeli produk atas pertimbangan harga mahal dianggap prestige. Mahasiswa cenderung menggunakan segala hal yang dianggap paling mewah, karena akan merasa lebih percaya diri dan dihargai kalau barang yang digunakan adalah produk mahal. 
e. Membeli produk hanya sekedar menjaga simbol status. Hal tersebut dapat menunjang sifat eksklusif dengan barang yang mahal dan memberi kesan berasal dari kelas sosial yang lebih tinggi.

f. Membeli produk karena unsur konformitas terhadap model yang mengiklankan. Mahasiswa cenderung meniru perilaku tokoh yang diidolakan dalam bentuk menggunakan segala sesuatu yang dipakai tokoh idolanya.

g. Munculnya penilaian bahwa membeli produk dengan harga mahal akan menimbulkan rasa percaya diri yang positif. Hurlock (1999) juga menambahkan bahwa dengan membeli produk yang mereka anggap dapat mempercantik penampilan fisik, mereka akan menjadi lebih percaya diri.

h. Mencoba lebih dari dua produk sejenis (brand berbeda). Hal ini dilakukan karena mahasiswa cenderung ingin melihat perbedaan antara khasiat produk yang satu dengan yang lainnya.

Dari pemaparan di atas, dapat dipahami bahwa perilaku konsumtif mahasiswa mulai menjadi kebiasaan yang dapat membentuk sebuah gaya hidup. Hal ini membawa mahasiswa ke dalam tindakan yang cenderung memprioritaskan penampilan luar, harga diri, serta mengikuti perkembangan di lingkungan sekitar agar setara. Kebiasaan ini menjadikan mahasiswa sulit untuk bersikap rasional. Pada mulanya mahasiswa diharapkan mampu bertindak rasional dalam menyikapi perkembangna yang ada. Memicu mahasiswa tidak lagi berorientasi pada masa depan, justru berorientasi pada gaya hidup yang mereka jalani pada masa sekarang. Seharusnya kampus merupakan tempat mahasiswa untuk menimba ilmu pengetahuan, bertukar pikiran, bersosialisasi sesama mahasiswa, dan lain sebagainya. Namun yang terlihat di era globalisasi ini, kampus seringkali dijadikan ajang pamer penampilan dan gaya hidup mahasiswa. Sehingga ketika banyak mahasiswa menerapkan gaya hidup konsumtif, kehidupan kampus semakin tidak jelas. Di sisi lain, kuatnya pengaruh teman sekelompok dalam perkuliahan terhadap penampilan, membuat para mahasiswa berusaha menampilkan dirinya 
sebaik mungkin agar tidak merasa ditolak oleh kelompoknya sendiri (Hurlock, 2012). Keinginan untuk meningkatkan rasa percaya diri dan ingin diterima membuat mahasiswa melakukan pembelian secara berlebihan, sehingga dapat menyebabkan terjadinya gejala gaya hidup membeli yang tidak wajar. Hal itu dilakukan agar terlihat menarik dengan menggunakan busana dan aksesoris, seperti sepatu, tas dan sebagainya yang dapat menunjang penampilan masa kini. Para mahasiswa juga tidak segan-segan untuk membeli barang yang menarik dan mengikuti trend yang sedang berlaku. Akibatnya, para mahasiswa tidak memperhatikan kebutuhannya ketika membeli barang. Kecenderungan untuk membeli barang yang diinginkan bukan yang dibutuhkan secara berlebihan dan tidak wajar inilah yang disebut dengan gaya hidup konsumtif.

Apabila dilihat dari sisi negatifnya, maka perilaku konsumtif pada mahasiswa akan menimbulkan berbagai dampak diantaranya : (1) Pola hidup yang boros dan akan menimbulkan kecemburuan sosial, karena mahasiswa konsumtif akan membeli semua barang yang diinginkan tanpa memikirkan harga barang tersebut murah atau mahal, barang tersebut diperlukan atau tidak, sehingga bagi yang tidak mampu mereka tidak akan sanggup untuk mengikuti pola kehidupan yang seperti itu. (2) Mengurangi kesempatan untuk menabung, karena mahasiswa konsumtif akan lebih banyak membelanjakan uangnya dibandingkan menyisih kan untuk ditabung. (3) Cenderung tidak memikirkan kebutuhan yang akan datang, mahasiswa konsumtif akan mengkonsumsi lebih banyak barang pada saat sekarang tanpa berpikir kebutuhannya di masa datang. Dengan melihat fenomena diatas, penting bagi peneliti untuk mengupayakan melalui layanan konseling behavior. Dengan layanan tersebut diharapkan dapat membantu mahasiswa dalam mengurangi perilaku hidup konsumtif.

Adapun bentuk intervensi dalam penanganan kecenderungan perilaku konsumtif dapat melalui konseling behavior karena memenuhi asumsi dasar dari 
bentuk tingkah laku manusia yang dipaparkan oleh teori behavioral menurut Skinner dalam Alwisol, 2010 antara lain :

a. Tingkah laku itu mengikuti hukum tertentu, artinya setiap peristiwa berhubungan secara teratur dengan peristiwa lainnya. Perilaku konsumtif ini muncul karena mekanisme pertahanan diri yang negatif terhadap tuntutan zamaan. Hal ini menyebabkan adanya pergeseran bentuk kedudukan kebutuhan dari sekunder menjadi primer dan tersier menjadi sekunder

b. Tingkah laku dapat diramalkan (diprediksikan), artinya perilaku konsumtif biasanya muncul karena adanya pengaruh dari lingkungan seperti kelonggaran yang diberikan orang tua dalam aspek finansial, status ekonomi atau pengaruh dari teman sebaya.

c. Tingkah laku manusia dapat dikontrol, artinya perilaku konsumtif dapat ditingkatkan maupun diturunkan intensitasnya tergantung dari bagaimana respon lingkungan terhadap munculnya kecenderungan perilaku tersebut.

\section{Konseling Behavior}

Penanganan perilaku konsumtif melalui konseling behavior dapat dilakukan dengan menerapkan pendekatan teori operant conditioning. Motif perilaku konsumtif tersebut dalam rangka memenuhi kepuasan dan keinginan untuk diakui. Dengan demikian perilaku konsumtif remaja dapat dimodifikasi dengan reinforcement atau respon yang akan mengikuti perilaku tersebut. Salah satu faktor yang dapat mempengaruhi perilaku konsumtif siswa adalah bentuk respon lingkungan terutama keluarga dan masyarakat terhadap perilaku yang muncul. Menurut Skinner, melalui pemberian reinforcement dapat memodifikasi perilaku, mengurangi frekuensi bahkan menghambat kemunculan perilaku yang tidak diinginkan atau penyimpangan perilaku.

Strategi yang dapat digunakan untuk menangani perilaku konsumtif berdasarkan asumsi behavioral dari Skinner adalah behavioral contract dan reinforcement. Behavioral Contract (Kontrak Perilaku) adalah persetujuan antara dua orang atau lebih (konselor dan klien) untuk mengubah perilaku tertentu pada 
klien, (Latipun, 2008). Kontrak berisi persetujuan tertulis dari pihak-pihak yang terlibat dalam proses konseling, utamanya konselor dan konseli tentang berbagai hal yang berhubungan dengan proses konseling seperti peran dan tanggung jawab, bentuk penguatan dan sanksi yang akan diberikan, aturan pemberian penguatan, dsb (Eko Darminto, 2007). Penggunaan teknik behavioral contract didasarkan pada pandangan bahwa penghentian perilaku menyimpang pada mahasiswa harus disertai dengan hadiah tertentu sesuai dengan perjanjian yang disepakati dan sebaliknya. Dalam hal ini individu mengantisipasi perubahan perilaku dikarenakan persetujuan bahwa konsekuensi akan muncul jika perilaku maladaptif terus terulang. Dalam teknik ini konselor memilih perilaku realistik dan dapat diterima oleh kedua belah pihak misalnya jika mampu menabung dengan jumlah ditentukan dalam jangka satu bulan akan mendapat reward. Setelah perilaku dimunculkan sesuai dengan kesepakatan, hadiah dapat diberikan kepada mahasiswa. Dalam terapi ini reinforcement positif terhadap perilaku yang ingin dibentuk lebih dipentingkan daripada pemberian hukuman jika perilaku tetap dilaksanakan. Dalam pelaksanaan kontrak perilaku yang bertujuan untuk memodifikasi perilaku tertentu, langkah-langkah yang digunakan yakni :

a. Memilih perilaku yang akan dirubah. Dalam pemilihan perilaku tersebut harus berasal dari persetujuan semua pihak, kemudian konselor juga perlu merasionalisasikan mengapa tingkah laku tersebut perlu diubah.

b. Menentukan bagaimana proses perilaku tersebut dapat dirubah.

c. Menentukan konsekuensi yang mengikuti setiap perilaku tersebut. Konsekuensi positif ditentukan sebagai respon terhadap proses perilaku yang telah disepakati dilaksanakan oleh konseli. Sedangkan respon negatif ditentukan sebagai respon jika konseli tidak mampu melaksanakan proses perilaku yang telah disepakati. 
d. Memilih siapa yang akan memberikan reinforcement terhadap setiap perilaku, bisa dipilih konselor sendiri atau kerja sama dengan orangtua tergantung keinginan konseli.

e. Evaluasi, pada proses ini awalnya konselor memberikan gambaran bagaimana mengevaluasi tingkah laku yang dimunculkan konseli sesuai dengan kontrak yang telah disepakati. Selanjutkan konselor memandirikan konseli untuk mengevaluasi sendiri setiap tingkah lakunya.

Secara lebih khusus pendekatan konseling behavioral menurut Skinner yang mengarah pada bentuk perilaku operant yakni perilaku yang dihasilkan oleh konsekuensi dari perilaku tersebut dapat diinternalisasikan dalam penanganan kecenderungan perilaku konsumtif. Kemunculan perilaku konsumtif dapat disertai dengan pemberian reinforcement untuk memodifikasinya. Pemberian reinforcement tersebut dilakukan konseling secara perorangan dengan teknik behavioral contract. Selain itu juga dalam kondisi diluar forum kontrak konselor tetap terus memberikan penguatan yang terus menerus (continous reinfocement) pada konseli. Diharapkan perlakuan tersebut dapat menjadi evaluasi sikap dan pembelajaran pada diri mahasiswa untuk menurunkan kecenderungan perilaku konsumtif.

\section{Penerapan Konseling Behavior Untuk Mengurangi Kecenderungan Perilaku Konsumtif Mahasiswa Psikologi 2018 UIN Malang}

Langkah pertama dalam penelitian ini yaitu peneliti melakukan penyebaran skala perilaku konsumtif, jenis skala yang digunakan yaitu skala model Likert dimana dalam skala tersebut berisi pernyataan-pernyataan yang dapat mengungkap mengenai perilaku konsumtif mahasiswa, adapun skala yang disebarkan pada siswa merupakan skala yang dibuat oleh peneliti dan telah diuji validitas dan reabilitasnya sehingga skala tersebut dapat digunakan untuk memperoleh data mana saja mahasiswa yang mempunyai kecenderungan perila ku konsumtif yang tinggi. Setelah melakukan penyebaran skala perilaku konsumtif 
kepada mahasiswa psikologi UIN Malang angkatan 2018, maka didapatkan 9 mahasiswa sebagai subyek penelitian yang memiliki kecenderungan perilaku konsumtif tinggi pada setiap indikator dan 3 mahasiswa yang memiliki kecenderungan perilaku konsumtif kategori sangat rendah. Berikut adalah tabel siswa yang memiliki kecenderungan perilaku konsumtif tinggi pada setiap indikatornya.

Tabel 1. Data Konseling Behavior

\begin{tabular}{|c|c|c|c|}
\hline No & Inisial & Nilai & Kategori \\
\hline 1 & UA & 92 & Sangat Rendah \\
\hline 2 & LM & 89 & Sangat Rendah \\
\hline 3 & MD & 90 & Sangat Rendah \\
\hline
\end{tabular}

Tabel 2. Nilai Subyek Penelitian pada Pretest

\begin{tabular}{lllllll} 
No & Inisial & \multicolumn{3}{c}{ Skor per Indikator } & \multicolumn{2}{c}{ Total } \\
Nilai & Kategori \\
\cline { 3 - 5 } & & Aktivitas & Minat & Opini & \\
\hline $\mathbf{1}$ & AR & 45 & 71 & 56 & 172 & Tinggi \\
\hline $\mathbf{2}$ & FA & 48 & 59 & 43 & 150 & Tinggi \\
\hline $\mathbf{3}$ & MFS & 45 & 59 & 41 & 145 & Tinggi \\
\hline $\mathbf{4}$ & MZR & 46 & 67 & 42 & 155 & Tinggi \\
\hline $\mathbf{5}$ & GT & 45 & 63 & 43 & 151 & Tinggi \\
\hline $\mathbf{6}$ & KN & 47 & 58 & 43 & 148 & Tinggi \\
\hline $\mathbf{7}$ & AT & 50 & 67 & 46 & 163 & Tinggi \\
\hline $\mathbf{8}$ & WS & 50 & 62 & 42 & 154 & Tinggi \\
\hline $\mathbf{9}$ & RK & 53 & 73 & 45 & 171 & Tinggi \\
\hline
\end{tabular}

Langkah berikutnya ke-9 mahasiswa diatas diberikan perlakuan selama tiga kali pertemuan. Untuk pertemuan pertama mahasiswa yang menjadi subyek 
penelitian membuat kontrak berdasarkan data pengeluaran mahasiswa selama 2 minggu agar mahasiswa dapat menyusun suatu aturan dalam kehidupan seharihari untuk menurunkan perilaku konsumtifnya. Aktivitas yang dilakukan konselor antara lain menanyakan catatan pengeluaran yang telah diminta pada pertemuan sebelumnya, meminta mahasiswa menjelaskan tentang catatan pengeluaran yang diminta oleh konselor selama dua minggu secara individual. Kemudian melakukan konseling pada masing-masing mahasiswa berkaitan dengan perilaku konsumtif, lalu konselor memberikan reinforcement berupa detail beragam contoh dampak negatif berperilaku konsumtif. Hal ini ditujukan untuk mencipatakan kondisi lingkungan yang mampu membuat mahasiswa merubah perilaku konsumtif yang dimilikinya, menyiapkan contoh bentuk kerangka kontrak yang akan dilakukan dengan siswa. Konselor meminta mahasiswa membaca dan mengisi kerangka kontrak yang telah diberikan sesuai yang diingkan konseli. Rentang waktu kontrak dilakukan selama 2 minggu. Dari pertemuan ini hasil yang didapatkan konselor mengetahui bahwa konseli memiliki niatan untuk mengubah perilakunya dengan melaksanakan tugas pada pertemuan sebelumnya secara baik dengan mencatat secara mendetail pengeluaran mereka selama dua minggu dan konseli mampu mengisi kontrak perilaku secara mandiri.

Untuk pertemuan kedua, konselor memberikan reinforcement secara klasikal. Serta memberikan reinforcement secara individu pada subjek penelitian agar mahasiswa semakin memahami tentang akibat perilaku konsumtif dan memikirkan alternatif cara mengurangi perilaku konsumtif tersebut. Secara klasikal konselor menyajikan manfaat memiliki kebiasaan menabung yang baik. Kebiasaan tersebut merupakan salah satu alternatif untuk menghentikan perilaku konsumtif mahasiswa. Untuk pertemuan ketiga sekaligus terakhir, konselor melakukan konseling individu mengenai hasil kontrak perilaku yang telah diberikan. Hal ini dimaksudkan untuk menilai pengaruh kontrak perilaku terhadap perilaku konsumtif mahasiswa. Aktivitas yang dilakukan pada pertemuan ini dengan masing-masing mahasiswa ialah konselor menanyakan tentang perubahan 
yang terjadi pada mahasiswa sebelum dan selama kontrak perilaku dilakukan. Kemudian konselor menuntun mahasiswa untuk membandingkan catatan pengeluaran mahasiswa sebelum kontrak dan selama masa kontrak. Kemudian konselor mengarahkan mahasiswa dalam memahami perbedaan da ta pengeluaran siswa sebelum kontrak dan selama masa kontrak.

Hasil yang diperoleh pada pertemuan diantaranya mahasiswa mengakui kebiasaan yang dilakukannya untuk membeli mengalami sedikit perubahan sebelum dan selama masa kontrak perilaku dengan konselor. Kebanyakan konseli beralasan bahwa pada awalnya penurunan perilaku konsumtif mereka yang terlihat dari perbandingan tingkat pengeluaran terjadi karena keinginan mereka untuk mendapat hadiah dan malas menjalankan hukuman yang mereka tentukan sendiri. Namun lama-kelaman setelah merasa tidak membeli barang-barang yang biasa mereka beli dan memilih mengumpulkan uang saku mereka ternyata tidak membawa akibat apa pun bagi mereka malah mereka punya tabungan, membuat mereka merasa lebih nyaman dengan kontrak yang mereka jalankan. Beberapa konseli juga mengakui saat mereka telah mempunyai tabungan, mereka ingin menambah jumlahnya menjadi lebih besar sehingga mereka dapat melewati godaan sale besar-besaran.

Selain itu, untuk pertemuan terakhir sesudah diberikan perlakuan konseling behavior, konselor kemudian juga memberikan post-test dan tidak lupa untuk menguatkan lagi komitmen mahasiswa agar tetap melatih diri untuk mengurangi peilaku konsumtifnya. Post-test ini berguna untuk mendapatkan perbedaan skor yang didapatkan sebelum dan sesudah diberikan perlakuan. Adapun data hasil post-test mahasiswa dapat dilihat dalam tabel berikut :

\begin{tabular}{llll}
\hline No & Nama & Nilai & Kategori \\
$\mathbf{1}$ & AR & 134 & Rendah \\
\hline $\mathbf{2}$ & FA & 135 & Rendah \\
\hline
\end{tabular}




\begin{tabular}{llll}
\hline $\mathbf{3}$ & MFS & 131 & Rendah \\
\hline $\mathbf{4}$ & MZR & 133 & Rendah \\
\hline $\mathbf{5}$ & GT & 137 & Rendah \\
\hline $\mathbf{6}$ & KN & 132 & Rendah \\
\hline $\mathbf{7}$ & AT & 138 & Rendah \\
\hline $\mathbf{8}$ & WS & 141 & Rendah \\
\hline $\mathbf{9}$ & RK & 135 & Rendah \\
\hline
\end{tabular}

Hasil treatment ini setelah diberikannya perlakukan, subyek diberikan pretest dan post-test. Secara keseluruhan tiap subyek penelitian memiliki kategori rendah, artinya telah terjadi penurunan skor dari tinggi (pada pre-test) hingga rendah (pada pos-test). Tidak hanya penurunan skor saja akan tetapi terdapat perubahan perilaku yang terjadi pada masing-masing subyek. Perbedaan perubahan yang terjadi pada subyek berbeda dikarenakan memiliki faktor permasalahan gaya hidup konsumtif yang berbeda pula.

Tabel total nilai pre-test dan pos-test mahasiswa

\begin{tabular}{ccccc}
\hline No & Nama & Pretest & Postest & Penurunan \\
$\mathbf{1}$ & AR & 172 & 134 & 38 \\
\hline $\mathbf{2}$ & FA & 150 & 135 & 15 \\
\hline $\mathbf{3}$ & MFS & 145 & 131 & 14 \\
\hline $\mathbf{4}$ & MZR & 155 & 133 & 22 \\
\hline $\mathbf{5}$ & GT & 151 & 137 & 14 \\
\hline $\mathbf{6}$ & KN & 148 & 132 & 16 \\
\hline $\mathbf{7}$ & AT & 163 & 138 & 13 \\
\hline $\mathbf{8}$ & WS & 154 & 141 & 36 \\
\hline $\mathbf{9}$ & RK & 171 & 135 & 193 \\
\hline
\end{tabular}




$\begin{array}{llll}\text { Rata-rata } & 156,5 & 135,1 & 21,4\end{array}$

Berdasarkan tabel diatas dapat diketahui hasil pretest dan postest pada subyek penelitian. Hasil prettest atau sebelum diberikan perlakuan konseling behavior dan hasil postest setelah diberikan konseling behavior terdapat penurunan sebesar 21,4. Dalam penelitian ini hasil penelitian di analisis data dengan menggunakan Uji Wilcoxon, dimana diperoleh hasil Zhitung= 2,670. Hasil ini selanjutnya dibandingkan dengan Ztabel $=1,645$. Adapun ketentuan pengujian bila Zhitung > Ztabel maka Ho ditolak dan Ha diterima. Maka dapat dikatakan sebagai berikut yaitu diperoleh Zhitung $=2,670>$ Ztabel $=1,645$ maka Ho ditolak dan Ha diterima. Berdasarkan penelitian yang telah dilaksanakan, terdapat penurunan perilaku konsumtif mahasiswa psikologi UIN Malang setelah dilakukan konseling behavior.

\section{Simpulan}

Dapat disimpulkan bahwa terdapat perubahan tingkat kecenderungan perilaku konsumtif pada mahasiswa psikologi UIN Malang setelah diberikan perlakuan berupa konseling behavior. Perbedaan skor tersebut ditunjukkan dengan penurunan skor yaitu AR sebesar 172 (tinggi) menjadi 134 (srendah), FA sebesar 150 (tinggi) menjadi 135 (rendah), MFS sebesar 145 (tinggi) menjadi 131 (rendah), MZR sebesar 155 (tinggi) menjadi 133 (rendah), GT sebesar 151 (tinggi) menjadi 137 (rendah), KN sebesar 148 (tinggi) menjadi 132 (rendah), dan AT sebesar 163 (tinggi) menjadi 138 (rendah), WS sebesar 154 (tinggi) menjadi 141 (rendah) dan RK sebesar 171 (tinggi) menjadi 135 (rendah).Dari perolehan data tersebut dapat menjawab rumusan masalah sekaligus menerima hipotesis alternatif (Ha) bahwa "Konseling behavior dapat digunakan untuk mengurangi kecenderungan perilaku konsumtif pada mahasiswa psikologi angkatan 2018 UIN Malang" 
Bagi peneliti selanjutnya yang mengambil variabel sama dapat mengisi kekosongan dari sudut lainya seperti berfokus indikator minat dan opini yang belum mengalami penurunan secara signifikan, atau variabel permasalahnya lainnya. Selain itu, mungkin dapat ditindak lanjuti dengan penelitian yang berbasis hubungan atau korelasi tentang konseling behavior. Hasil penelitian ini dapat dijadikan sebagai suatu acuan untuk melakukan penelitian yang lebih luas dan komprehensif mengenai penerapan konseling behavior untuk menurunkan kecenderungan perilaku konsumtif mahasiswa. Diharapkan peneliti selanjutnya dapat mengembangkan instrumen pengukur perilaku konsumtif dengan pengembangan indikator dan deskriptor angket. Penelitian ini masih terbatas dengan hanya mengukur perilaku menggunakan angket, selebihnya diharapkan ditambah dengan asesmen tes yang lain. Selain itu teknik behavior yang digunakan juga dapat dikembangkan dengan menggunakan teknik selain behaviour contract dan reinforcement, sebagai alternatif penyelesaian masalah. Selain itu, perlu kiranya juga diperhatikan jarak serta lamanya setiap pertemuan dalam konseling karena mempengaruhi keberhasilan perilaku mahasiswa. 


\section{DAFTAR PUSTAKA}

Sumartono. (2002). Terperangkap dalam iklan. Bandung: Alfabeta

Santrock, John W. (2003). Adolescence Perkembangan Remaja 6th Edition. Jakarta : Erlangga

Darminto, Eko. (2007). Ketrampilan-Ketrampilan Dasar Dalam Konseling. Surabaya : Unesa University Press.

Latipun. (2008). Psikologi Konseling. Malang : UMM Press

Prabu, Anwar Mangkunegara. (2009). Perilaku Konsumen. Bandung : PT Refika Adiatama

Wagner, (2009). Gaya hidup "shopping mall" sebagai bentuk perilaku konsumtif pada remaja di perkotaan (kasus: konsumen remaja di tiga one stop shopping mall), skripsi tidak diterbitkan. Bogor : Fakultas Ekologi Manusia IPB, http://repository.ipb.ac.id/handle/123456789/12504, diakses tanggal 20 Maret 2021

Sugiyono (2010). Metode Penelitian Pendidikan Pendekatan Kuantitatif, kualitatif, dan $R \& D$. Bandung: Alfabeta.

Hotpascaman, S. (2010). Hubungan antara Perilaku Konsumtif dengan Konformitas pada Remaja. Volume 2 Nomor 1 Juli 2010.

Sarwono, Sarlito W. (2011). Psikologi Remaja. Jakarta : PT Rajagrafindo Persada

Gumulya, J., \& Widiastuti, M. (2013). Pengaruh Konsep Diri terhadap Perilaku Konsumtif Mahasiswa Universitas Esa Unggul. Jurnal Psikologi. Volume 11 Nomor 1 Februari 2013.

Rahayuningsih, Y. D. (2011). Hubungan Antara Kontrol Diri dengan Perilaku Konsumtif Pada Mahasiswa. Volume 3 Nomor 1 September 2011.

Noviza, N. (2011). Konseling Teman Sebaya (Peer Counseling) Suatu Inovasi Layanan Bimbingan Konseling Di Perguruan Tinggi. Jurnal IAIN Raden Fatah Palembang. Volume 2 Nomor 21 Januari 2011.

Suryabrata. (2012). Psikologi Kepribadian. Jakarta : PT. Raja Grafindo Persada. 